\title{
CLIMATE CHANGE AND EFFECTS ON VEGETATION IN VERACRUZ, MEXICO: AN APPROACH USING ECOLOGICAL NICHE MODELLING
}

\author{
Israel Estrada-Contreras ${ }^{1}$, Miguel Equihua ${ }^{1,4}$, Gonzalo Castillo-Campos ${ }^{2}$ \\ y Octavio Rojas-Soto 3
}

\author{
${ }^{1}$ Instituto de Ecología, A.C., Red de Ambiente y Sustentabilidad, Carretera antigua \\ a Coatepec 351, El Haya, 91070 Xalapa, Veracruz, Mexico. \\ ${ }^{2}$ Instituto de Ecología, A.C., Red de Biodiversidad y Sistemática, Carretera antigua \\ a Coatepec 351, El Haya, 91070 Xalapa, Veracruz, Mexico. \\ ${ }^{3}$ Instituto de Ecología, A.C., Red de Biología Evolutiva, Carretera antigua a \\ Coatepec 351, El Haya, 91070 Xalapa, Veracruz, Mexico. \\ ${ }^{4}$ Author for correspondence: miguel.equihua@inecol.mx
}

\begin{abstract}
According to the last report of the Intergovernmental Panel on Climate Change, human activities are the main responsible for global warming due to the increase in the atmospheric concentration of greenhouse gases. This process is already causing changes in the geographical distribution of species as well as alterations in phenology. With this background, it is interesting to study the expected trends of change to be displayed by flora and fauna to face the new environmental conditions. This paper explores the likely changes in the composition of the main vegetation types in the state of Veracruz, Mexico under a climate change scenario. We analyzed the geographical and ecological patterns of change in a group of 51 characteristic species commonly associated to tropical evergreen forest, coniferous forest and cloud forest present in Veracruz. The approach followed was based on the technique of ecological niche modelling carried out with the Genetic Algorithm for Rule-set Production (GARP) and variables of future climatic condition (located by 2050 in time) estimated for an A2 scenario which is devised for a situation where humanity would be generating medium to high emissions. The results obtained for the current vegetation of Veracruz suggest a potential impact inducing 53\% distribution change for tropical evergreen forest, $16 \%$ for coniferous forest and $49 \%$ for cloud forest. The results also suggest that some species may be extirpated from the state of Veracruz under the conditions expected by 2050, while a few others may find right conditions to increase their distribution.
\end{abstract}

Key words: cloud forest, coniferous forest, GARP, tropical evergreen forest, Veracruz. 


\section{RESUMEN}

De acuerdo con el último informe del Panel Intergubernamental sobre Cambio Climático, las actividades humanas son las principales responsables del calentamiento global observado en las últimas décadas y se debe al incremento en la concentración atmosférica de gases de efecto invernadero. Este proceso ya está causando cambios en la distribución geográfica de las especies, así como alteraciones en la fenología. En tal contexto, es interesante estudiar las posibles tendencias de cambio que podrían presentar la flora y fauna para hacer frente a las nuevas condiciones del medio ambiente. En este trabajo se exploran los posibles cambios en la composición de los principales tipos de vegetación en el estado de Veracruz, México, ante un escenario de cambio climático, mediante el análisis de los patrones de alteración geográfica y ecológica de un grupo de 51 especies comúnmente asociadas al bosque tropical perennifolio, el bosque de coníferas y el bosque mesófilo de montaña, presentes en el estado. El enfoque adoptado se basa en la técnica de modelado de nicho ecológico realizado con el Algoritmo Genético para la Producción de grupos de Reglas (GARP) y variables climatológicas estimadas para un escenario A2 que corresponde a una humanidad que genera emisiones medias-altas y derivan de proyecciones hechas a partir de las condiciones actuales hacia el año 2050. Los resultados obtenidos para la superficie actual de la vegetación del estado de Veracruz sugieren una afectación potencial de 53\% del área de distribución para el bosque tropical perennifolio, de 16\% para el bosque de coníferas y de $49 \%$ para el bosque mesófilo de montaña. Además, apuntan a que algunas especies tienen alta probabilidad de resultar extirpadas de la entidad bajo las condiciones esperadas en el 2050, mientras que otras encontrarán las condiciones adecuadas para incrementar su distribución.

Palabras clave: bosque de coníferas, bosque mesófilo de montaña, bosque tropical perennifolio, GARP, Veracruz.

\section{INTRODUCTION}

The fourth report of the Intergovernmental Panel on Climate Change (Anonymous, 2007) recognizes human activities as the main causes of global warming, provides high certainty for its existence and establishes that its effects are already under way. Climate change means that new long term environmental regimes shall emerge, with the potential to challenge plant populations in their ability to survive under the new conditions, both through acclimatization, if these are present within 
their potential niches (Vetaas, 2002), or by adaption if new conditions are beyond their potential niche (Holt, 1990; Holt and Gaines, 1992). There are only a few general alternatives for the survival of the species in response to climate change: movement, physiological acclimation and adaptation (in terms of evolutionary genetic change) otherwise, extirpation or extinction occur in extreme cases (Holt, 1990; Melillo et al., 1995). If species are capable of rapid evolutionary change or have a wide range of physiological tolerance, it is possible that adaptation or acclimation to changing environmental conditions take place. If species are sufficiently mobile, we can continuously trace the geographical relocation of their ecological niches (Pearson and Dawson, 2005; Engler et al., 2009).

Ecological niche modelling (ENM) has become a basic tool for the study of changes in the geographical and ecological distributions of species to global climate change (Pearson and Dawson, 2003; Peterson et al., 2004). Among a wide variety of algorithms that are currently available (Elith et al., 2006; Phillips et al., 2006; Elith et al., 2010) to generate ecological niche models, we used the Genetic Algorithm for Rule-set Production (GARP by Stockwell and Peters, 1999). This is an evolutionary computational algorithm which has been extensively tested on the prediction of the geographical distribution of species (Anderson et al., 2002; Peterson et al., 2002; Martínez-Meyer et al., 2004). Additionally, their behavior on extrapolation exercises is well documented (Peterson, 2003a, b; Peterson et al., 2005).

Mexico is a region where biotas of Nearctic and Neotropical origin are mixed. Many species reach here the boundary of their distribution range as an expression of the limit of their physiological tolerance. This results in the border effects already described in relation to the so-called "Mexican Transition Zone." Therefore, the main objective of this study was to analyze and synthesize the potential impact of global climate change by 2050 , on the most important vegetation communities of Veracruz from an autoecological analysis perspective (ecological niche modeling of species in particular). The impacts were estimated as distribution range shifts (area size, altitude and latitude) in the tropical evergreen forest, coniferous forest and cloud forest (sensu Rzedowski, 1978), present in the state of Veracruz. The geographical location of the state of Veracruz gives a setting of tropical characteristics, but these are modified in part by the influence of the mountain ranges, mainly in the west; climates therefore vary from very hot to very cold. Precipitation ranges from less than 500 millimeters $(\mathrm{mm})$ per year in some places in the north to about 4000 $\mathrm{mm}$ in the south. This environmental variation makes Veracruz one of the most biologically diverse states in the country. Almost all vegetation types described for Mexico are found here (Rzedowski, 1978). 
Based on the Ecological Niche Modelling approach, we developed potential future distribution ranges of the major components of the main vegetation types in the state of Veracruz and surroundings areas. The idea we pursue assumes that the sum of climatic niches of individual species (autoecology) could allow the reconstruction of communities to a certain degree, considering that they share similar environmental requirements. We also used this approach to analyze the current conditions under which species live and to make projections under different scenarios of global development. The overall goal was to describe the trends of change in the vegetation distribution, assuming the physiological range documented should allow to accurately predict expected changes in distribution, because the current human induced climate change is apparently giving almost no chance to genetic adaptive development (Holt, 1990).

\section{METHOD}

Selection of species and vegetation types

We generated a list of plant species (mainly trees) dominant and characteristic of either coniferous forest, cloud forest or tropical evergreen forest through a thorough review of literature about the vegetation of the state of Veracruz. The references used for this purpose were: Miranda and Hernández X. (1963); Gómez-Pompa (1966); Pennington and Sarukhán (1968); Gómez-Pompa et al., (1972); Anonymous (1975); Valdivia (1976); Gómez-Pompa (1977); Vázquez (1977); Del Amo (1978); Lozano (1979); Rzedowski (1978); Ramírez and Palma (1980); Zolá (1980); Correa (1981); Ramírez (1981); Gerez (1982); Williams-Linera (1982); Zolá (1984); Acevedo (1988); Martínez (1988); Blanco and Romero (1989); Vázquez (1989); CastilloCampos (1991); Durán (1992); Gutiérrez (1993); Martínez (1993); Medina-Abreo and Castillo-Campos (1993); Aquino (1996); Rzedowski (1996); González et al., (1997); Luna (1997); Zamora and Castillo-Campos (1997); Ramírez (1998); Heredia (1999); Ramírez (1999); Anonymous (2000); Ávila and López (2001); Godínez and López (2002); Castillo-Campos et al., (2003); Flores and Galindo-González (2004); Ruán (2006); Williams-Linera (2007); García et al., (2008).

Once the list of species was assembled, we used the MultiVariate Statistical Package (MVSP) version 3.1 (Kovach, 1999) to perform a cluster analysis through the method UPGMA (Unweighted Pair Group Method using Arithmetic averages) along with the Jaccard index, as a metric based on the calculation of the similarity in the "sinecological affinity" of selected species. From the groups obtained from 
MVSP, we made a selection of species for coniferous, cloud and tropical evergreen forest. Finally, the selected species were considered characteristic (frequent in the case of tropical evergreen forest) or non-dominant (associated) that we regarded representative of each vegetation type, according to the literature reviewed. Georeferenced localities of specimens of each of the selected species were obtained from the herbarium XAL of the Institute of Ecology, A.C.

Ecological niche modeling (ENM)

GARP generates a niche model for a species, aiming to characterize the environmental conditions under which it is estimated that the species should be able to thrive. Hence, it assumes that under those conditions the species is able to maintain populations without immigration (Stockwell and Peters, 1999). Although MAXENT is another algorithm commonly used, the differences between these two algorithms should not be a cause for concern (Tsoar et al., 2007; Peterson and Nyári, 2008; Warren et al., 2008). Albeit MAXENT achieves greater predictive success particularly in small sample sizes (Pearson et al., 2007), it has a relative inability to predict other time situations as well as to large areas not sampled. With respect to this, GARP has been found to work better in both situations (Peterson et al., 2007).

For the characterization of the ecological niche of the selected species, we used extreme temperatures and precipitation values (temperature of the warmest and the coldest month, precipitation of wettest and driest month). We selected these variables based on their physiological importance in combination with the compound topographic index (CTI) and slope; all variables with a spatial resolution of 30 " ( $\sim 0.86 \mathrm{~km}$ per pixel). The last two variables were obtained from the HYDRO1k Project (Anonymous, 2001), while the remaining variables were obtained from the WorldClim project database (Hijmans et al., 2005). Climatic variables such as maximum temperature, minimum temperature and precipitation can be particularly useful, since they coincide with physiological tolerances at regional scales (Peterson and Cohoon, 1999; Parra et al., 2004). In addition, as Gómez-Pompa (1977) suggests, extreme temperatures, especially the minimum, may be the values that have greater significance for the distribution of species. However, a combination of climatic and topographic features such as elevation and slope often produces better results (Parra et al., 2004), because topographic features could accurately map the behavior of several climatic variables to a detail that is difficult to detect with meteorological ground measures.

The modelling training region was established based on the idea that the species have the ability to disperse to certain geographical areas as long as they 
have the chance (e.g. crossing barriers) to reach such areas. Therefore, although we focused on the state of Veracruz, the records from the surrounding states (Tamaulipas, San Luis Potosí, Hidalgo, Puebla, Oaxaca, Chiapas and Tabasco; Fig. 1) were also considered. The extent of the study area corresponded to the continental surface included within the $14^{\circ} 29^{\prime}$ and $27^{\circ} 48^{\prime} \mathrm{N}$ latitude and $90^{\circ} 16^{\prime}$ and $102^{\circ} 19^{\prime} \mathrm{W}$ longitude. In the training process, we used $50 \%$ of the records for training and at least 20 training points.

We used estimated values for both current conditions and 2050 forecasts under a development scenario A2 according to projections produced by the Canadian Centre for Climate Modelling and Analysis (CCCMA). Climate variables were combined with record points of selected species and 100 models were generated by GARP. With these models a consensus map was integrated from the average of the top 10 maps ("Best subsets") selected based on low values of errors of omission and commission interim agreement as suggested by Anderson et al. (2003).

To produce a delimitation of the coniferous and cloud forests maps, we used the species considered as dominant to generate a consensus map with the sum of these species, whereas with the remaining non-dominant species we generated the other consensus map. Next, we overlaid the resulting dominant and associated species consensus maps and we obtained a final map that was produced by intersecting these two maps. For the reconstruction of most of the vegetation types we considered only those areas where the coincidence of overlapping species areas included more than $70 \%$ of all the modelled species either dominant or associated. This largely artificial threshold of $70 \%$ was based on the general correspondence to the polygon limits of the primary vegetation map from Anonymous (2003). In the case of the tropical evergreen forest, the overlap of the consensus maps was similar but for this vegetation type, all species were considered the same in terms of their dominance.

To establish whether our representation of modeled vegetation resembled natural vegetation units to a certain degree, we compared the maps obtained with the map of primary vegetation (Anonymous, 2003), which is defined as vegetation that would develop in an area under similar environmental conditions to the current ones, without human influence. Finally, to assess possible future impact of the vegetation types studied here, we contrasted the map of vegetation and land use of the state of Veracruz (Castillo-Campos et al., 2011) with the current potential distribution areas and 2050 forecast modeling. We regarded the surface in our 2050 potential vegetation maps outside of the current vegetation type maps of Veracruz we produced as the area susceptible to climate change under the chosen scenario. 


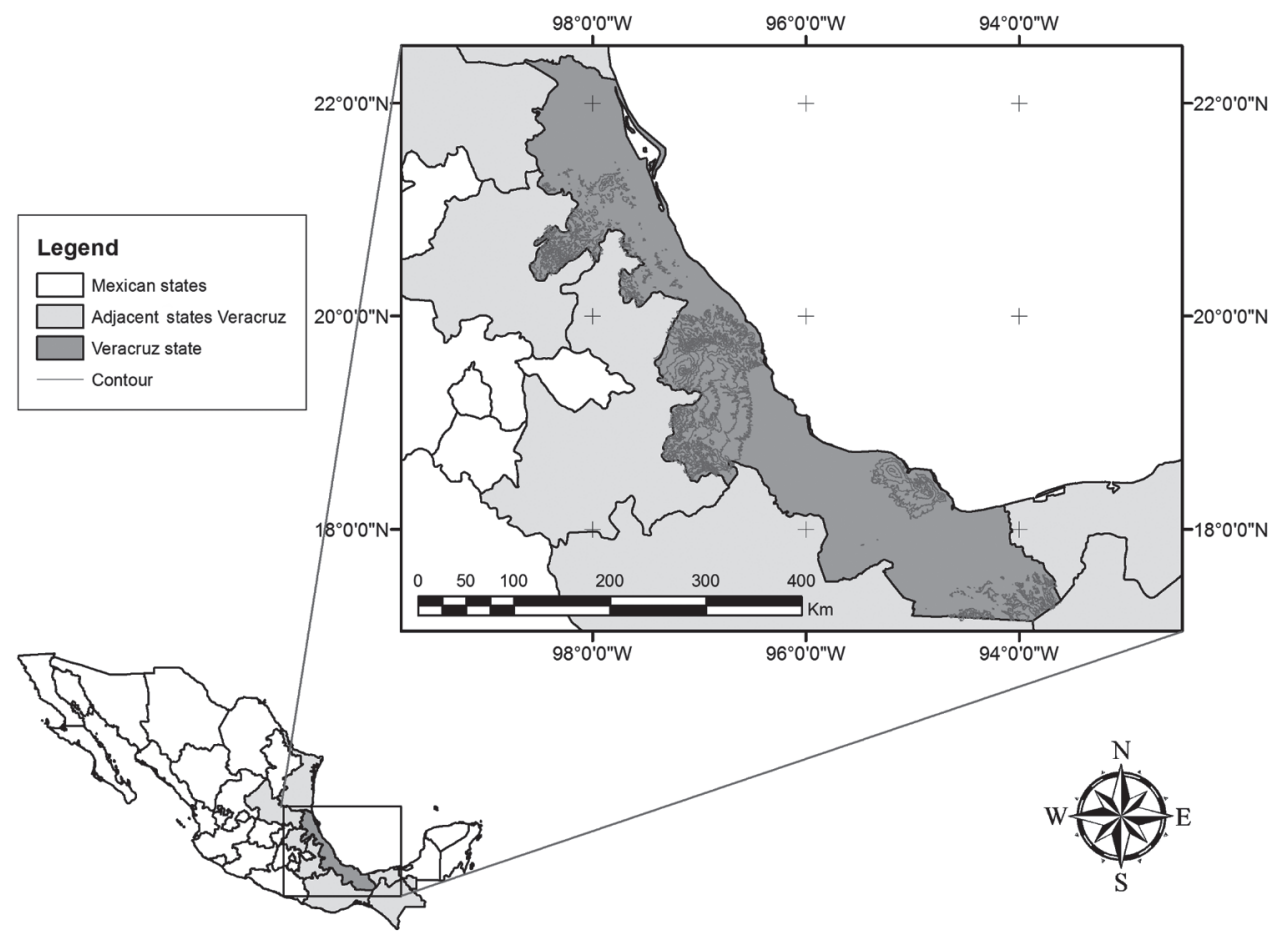

Fig. 1. Location of the state of Veracruz and study area.

\section{RESULTS}

The 10 "best-subset" models for the species of the three vegetation types presented $x^{2}$ values that ranged from 61.86 to 371.51 for tropical evergreen forest, from 74.96 to 2856.87 for coniferous forest and from 2.69 to 115.76 for cloud forest. All were statistically significant $(P<0.05)$.

Ecological niche models of all selected species of tropical evergreen forest projected to 2050 showed a smaller potential range in more than $50 \%$ of the species compared to the current distribution (Table 1). Five of them likely will not encounter right conditions for their survival within the limits of Veracruz. In the case of coniferous forest, the potential geographic distributions of the selected species do not show a common trend. While some species increase their potential distribution in the state of Veracruz, the distribution of others decrease, probably indicating a mixture of lineages from contrasting biogeographical affinities. However, 
Table 1. Selected species of tropical evergreen forest and approximate area of potential distribution for the state of Veracruz.

\begin{tabular}{llcrlrc}
\hline Family & Species & Records & \multicolumn{3}{c}{ Potential distribution in Veracruz } \\
\cline { 4 - 6 } & & & $\begin{array}{c}\text { Present } \\
\left(\mathrm{km}^{2}\right)\end{array}$ & $\begin{array}{r}2050 \\
\left(\mathrm{~km}^{2}\right)\end{array}$ & $\begin{array}{c}\text { Change } \\
(\%)\end{array}$ \\
\hline Bombacaceae & Bernoullia flammea & 16 & 51135 & 18816 & -63.20 \\
Burseraceae & Bursera simaruba & 198 & 63016 & 647 & -98.97 \\
Caessalpinaceae & Dialium guianense & 35 & 23841 & 0 & -100.00 \\
Clusiaceae & Calophyllum brasiliense & 42 & 40859 & 0 & -100.00 \\
Combretaceae & Terminalia amazonia & 25 & 20146 & 4217 & -79.07 \\
Lauraceae & Licaria capitata & 69 & 45745 & 80 & -99.83 \\
Meliaceae & Swietenia macrophylla & 17 & 25610 & 9989 & -61.00 \\
Moraceae & Brosimum alicastrum & 144 & 58678 & 0 & -100.00 \\
Moraceae & Ficus tecolutensis & 18 & 55068 & 42 & -99.92 \\
Moraceae & Pseudolmedia oxyphyllaria & 50 & 23561 & 0 & -100.00 \\
Ulmaceae & Aphananthe monoica & 37 & 48254 & 20905 & -56.68 \\
Vochysiaceae & Vochysia guatemalensis & 29 & 36309 & 0 & -100.00 \\
\hline
\end{tabular}

the species that could be more affected towards 2050 is Pinus oocarpa (nearctic), while the species that is more likely to survive is Fuchsia microphylla (neotropical) (Table 2).

We found that most of the selected species characteristic of cloud forest are likely to decline by 2050. Certainly, the critical factor is the potential loss of humidity, which is highly influential for this community. It is noteworthy that Quercus laurina is the only species of this group that could find better conditions for its sustained presence within Veracruz by 2050 (Table 3).

As a way to assess the accuracy of our findings, we overlaid the potential distribution models obtained with the corresponding vegetation map of current land use and vegetation. The result of this comparison showed values that match the geographical coverage on 53\% (4123.89 $\left.\mathrm{km}^{2}\right), 71 \%\left(856.88 \mathrm{~km}^{2}\right)$ and $85 \%\left(1706.32 \mathrm{~km}^{2}\right)$ for tropical evergreen forest, coniferous forest and cloud forest, respectively. Based on our results, the prediction for 2050 in the state of Veracruz shows a possible decrease of the surface of tropical evergreen, coniferous and cloud forest in 53\%, 16\% and $49 \%$, respectively. For the coverage of tropical evergreen forest (Fig. 2-d) and cloud forest (Fig. 2-f) in the region of Veracruz and neighboring states, we estimated 
Table 2. Selected species of coniferous forest and approximate area of potential distribution for the state of Veracruz.

\begin{tabular}{|c|c|c|c|c|c|c|}
\hline & \multirow[t]{2}{*}{ Family } & \multirow[t]{2}{*}{ Species } & \multirow[t]{2}{*}{ Records } & \multicolumn{3}{|c|}{ Potential distribution in Veracruz } \\
\hline & & & & $\begin{array}{l}\text { Present } \\
\left(\mathrm{km}^{2}\right)\end{array}$ & $\begin{array}{l}2050 \\
\left(\mathrm{~km}^{2}\right)\end{array}$ & $\begin{array}{c}\text { Change } \\
(\%)\end{array}$ \\
\hline \multirow{11}{*}{ 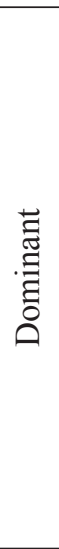 } & Cupressaceae & Juniperus deppeana & 23 & 1471 & 461 & -68.65 \\
\hline & Pinaceae & Abies hickelii & 7 & 2602 & 1913 & -26.50 \\
\hline & Pinaceae & Abies religiosa & 27 & 5438 & 6184 & 13.73 \\
\hline & Pinaceae & Pinus ayacahuite & 16 & 3844 & 3193 & -16.94 \\
\hline & Pinaceae & Pinus hartwegii & 22 & 4752 & 4927 & 3.67 \\
\hline & Pinaceae & Pinus leiophylla & 12 & 3517 & 3177 & -9.66 \\
\hline & Pinaceae & Pinus montezumae & 37 & 7147 & 5912 & -17.28 \\
\hline & Pinaceae & Pinus oocarpa & 25 & 25249 & 529 & -97.91 \\
\hline & Pinaceae & Pinus patula & 55 & 7055 & 7074 & 0.28 \\
\hline & Pinaceae & Pinus pseudostrobus & 62 & 7854 & 6760 & -13.93 \\
\hline & Pinaceae & Pinus teocote & 45 & 5778 & 5761 & -0.30 \\
\hline \multirow{8}{*}{ 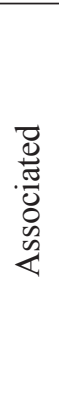 } & Asteraceae & Baccharis conferta & 90 & 7485 & 7576 & 1.21 \\
\hline & Asteraceae & Bidens triplinervia & 58 & 7802 & 7902 & 1.28 \\
\hline & Asteraceae & Senecio grandifolius & 22 & 9868 & 3473 & -64.81 \\
\hline & Betulaceae & Alnus acuminata & 104 & 8509 & 6897 & -18.94 \\
\hline & Ericaceae & Arbutus xalapensis & 43 & 9554 & 9127 & -4.46 \\
\hline & Fabaceae & Lupinus montanus & 24 & 4648 & 4854 & 4.42 \\
\hline & Onagraceae & Fuchsia microphylla & 62 & 3644 & 7868 & 115.93 \\
\hline & Rosaceae & Rubus adenotrichus & 24 & 7399 & 5134 & -30.61 \\
\hline
\end{tabular}

a substantial decrease in their future potential distribution that could reach nearly 100\% (Fig. 2-g) and more than 60\% (Fig. 2-i), respectively (Table 4). In contrast, we expect that the representation of coniferous forest should increase by 2050 in nearly 20\% (Fig. 2-h) of its current potential distribution (Fig. 2-e and Table 4).

Finally, the average values of the coverage of all vegetation types, as projected from present conditions towards those expected in 2050, throughout the region of Veracruz and neighboring states, suggest an overall latitudinal shift southwards, although showing different levels of magnitude for each vegetation type. There is also a displacement to areas with higher elevation in the tropical evergreen forest (218 to $575 \mathrm{~m}$ ) and cloud forest (1498 to $1585 \mathrm{~m}$ ). This seems to match the rising trend of the 
Table 3. Selected species of cloud forest and approximate area of potential distribution for the state of Veracruz.

\begin{tabular}{|c|c|c|c|c|c|c|}
\hline & \multirow[t]{2}{*}{ Family } & \multirow[t]{2}{*}{ Species } & \multirow[t]{2}{*}{ Records } & \multicolumn{3}{|c|}{ Potential distribution in Veracruz } \\
\hline & & & & $\begin{array}{c}\text { Present } \\
\left(\mathrm{km}^{2}\right)\end{array}$ & $\begin{array}{l}2050 \\
\left(\mathrm{~km}^{2}\right)\end{array}$ & $\begin{array}{c}\text { Change } \\
(\%)\end{array}$ \\
\hline \multirow{11}{*}{$\begin{array}{l}\stackrel{\Xi}{\Xi} \\
\stackrel{\Xi}{\Xi} \\
\stackrel{\Xi}{0}\end{array}$} & Betulaceae & Carpinus caroliniana & 69 & 8223 & 4233 & -48.52 \\
\hline & Clethraceae & Clethra mexicana & 38 & 12922 & 8407 & -34.94 \\
\hline & Fagaceae & Quercus affinis & 63 & 8474 & 8211 & -3.10 \\
\hline & Fagaceae & Quercus germana & 20 & 19023 & 6696 & -64.80 \\
\hline & Fagaceae & Quercus leiophylla & 24 & 5515 & 4066 & -26.27 \\
\hline & Fagaceae & Quercus xalapensis & 39 & 11782 & 3902 & -66.88 \\
\hline & Hamamelidaceae & Liquidambar styraciflua & 21 & 13486 & 4558 & -66.20 \\
\hline & Juglandaceae & Oreomunnea mexicana & 11 & 6831 & 3805 & -44.30 \\
\hline & Sabiaceae & Meliosma alba & 44 & 9445 & 6047 & -35.98 \\
\hline & Staphyleaceae & Turpinia insignis & 78 & 11018 & 6727 & -38.95 \\
\hline & Ulmaceae & Ulmus mexicana & 27 & 12916 & 869 & -93.27 \\
\hline \multirow{9}{*}{ 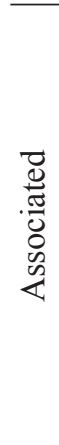 } & Araliaceae & Oreopanax xalapensis & 70 & 24157 & 6543 & -72.91 \\
\hline & Clethraceae & Clethra macrophylla & 47 & 7579 & 4876 & -35.66 \\
\hline & Euphorbiaceae & Alchornea latifolia & 69 & 28954 & 10858 & -62.50 \\
\hline & Fagaceae & Quercus laurina & 54 & 6871 & 7375 & 7.34 \\
\hline & Juglandaceae & Alfaroa mexicana & 14 & 10072 & 4221 & -58.09 \\
\hline & Melastomataceae & Miconia glaberrima & 78 & 9113 & 687 & -92.46 \\
\hline & Myrtaceae & Eugenia xalapensis & 12 & 5685 & 3948 & -30.55 \\
\hline & Podocarpaceae & Podocarpus matudae & 14 & 6855 & 4278 & -37.60 \\
\hline & Styracaceae & Styrax glabrescens & 66 & 7755 & 2957 & -61.88 \\
\hline
\end{tabular}

Table 4. Potential distribution of the current and projected by 2050 tropical evergreen, boreal and cloud forest to Veracruz and neighboring states.

\begin{tabular}{lcccccc}
\hline Forest type & $\begin{array}{c}\text { Primary } \\
\text { vegetation } \\
\end{array}$ & \multicolumn{2}{c}{$\begin{array}{c}\text { Match current potential } \\
\text { distribution }\end{array}$} & \multicolumn{3}{c}{ Potential distribution $\left(\mathrm{km}^{2}\right)$} \\
\cline { 3 - 7 } & & $\mathrm{km}^{2}$ & $\%$ & Present & 2050 & Change (\%) \\
\hline Tropical evergreen & 114817.78 & 52777.57 & 45.97 & 62481.72 & 1392.62 & -97.77 \\
Coniferous & 49432.43 & 13047.26 & 26.39 & 20848.02 & 25370.30 & 121.69 \\
Cloud & 25421.37 & 11175.93 & 43.96 & 23343.23 & 9246.87 & -60.39 \\
\hline
\end{tabular}


Tropical evergreen forest
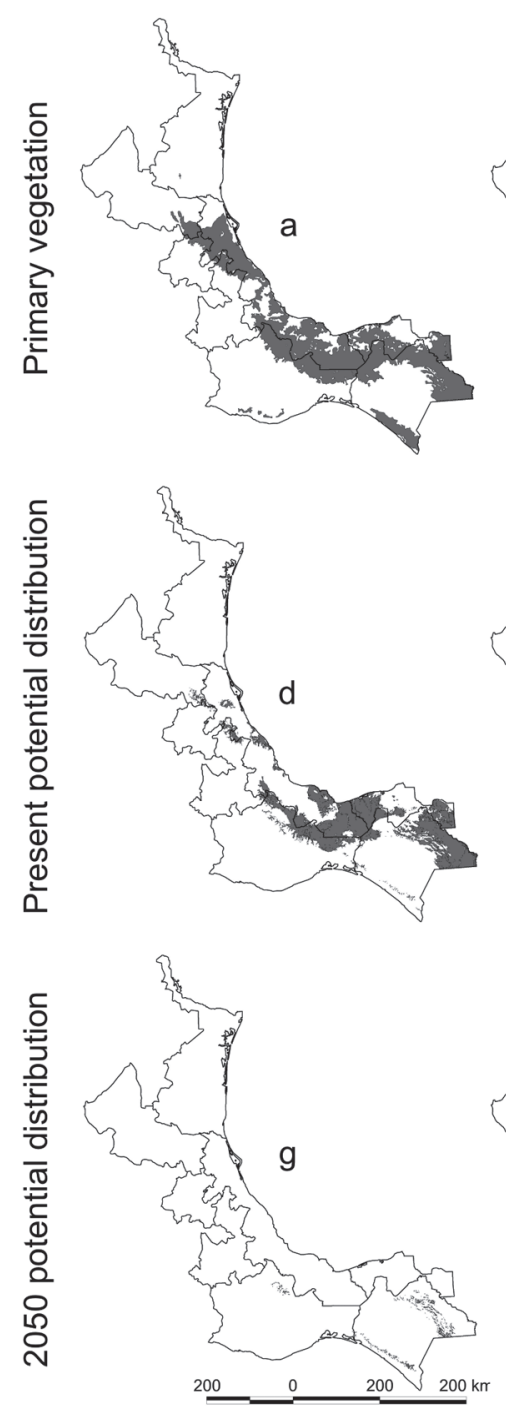

Boreal forest
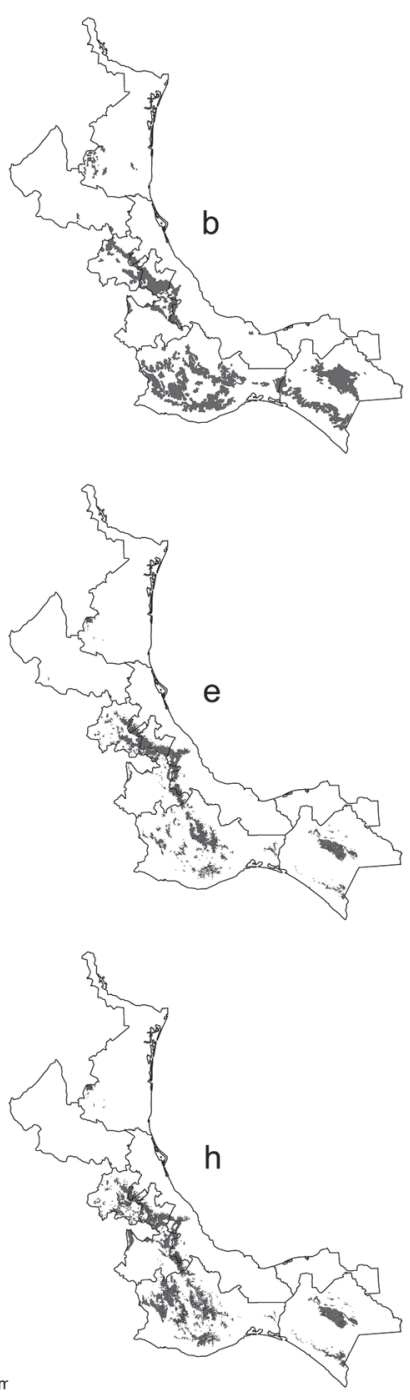

Cloud forest
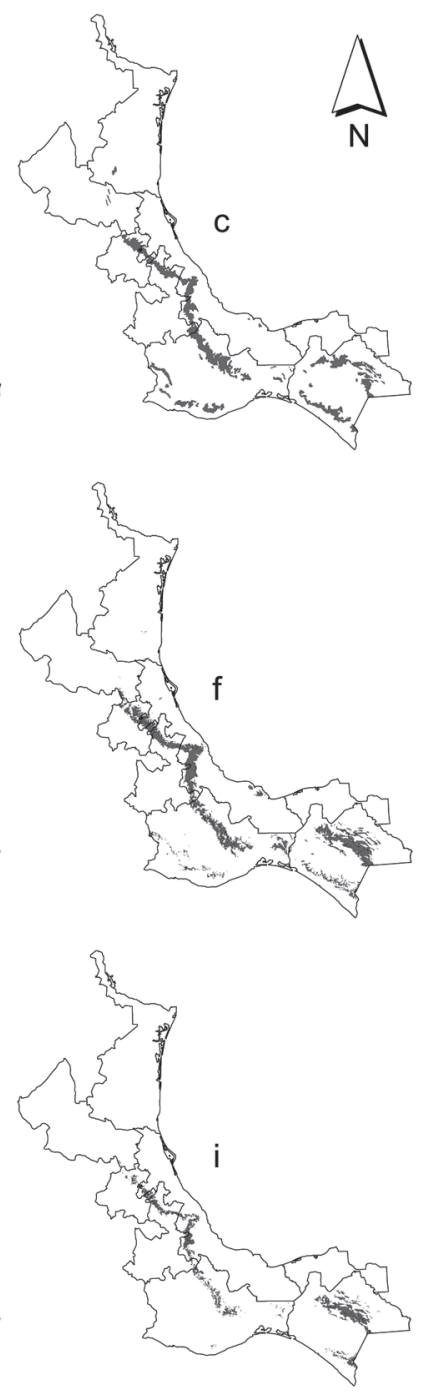

Fig. 2. Spatial patterns of primary vegetation, current and 2050 potential distribution of tropical evergreen, boreal and cloud forest under an emissions scenario A2 for the region of Veracruz and neighboring states. 
strip of fog that has already been described (Still et al., 1999). In the case of the coniferous forest, we found a likely shift towards lower elevation in 2050 (2307 to $2275 \mathrm{~m}$ ).

\section{DISCUSSION}

The analysis of potential future distribution ranges of plant communities has been the subject of various studies and discussions (Osborne et al., 2000; Scheiter and Higgins, 2009; Chaturvedi et al., 2011). One consequence of this has been an increase of discrepancies on the predictions of the future distribution of forests in Mexico and thus on the various possible levels of impact that will have climate change on the different vegetation types in the country. After applying a sensitivity model, the results obtained by Villers and Trejo (1997) suggested that more than half of Mexico would suffer changes in temperature and precipitation conditions. These results agree with those found by Arriaga and Gómez (2004), since both studies suggested that the vegetation types most affected by climate change might be the coniferous, Quercus and cloud forest as well as desert scrub. They also noted that the tropical evergreen forest may show an increase in its surface in the future.

Regionally, our results agree with the work of Villers and Trejo (1997) and Arriaga and Gómez (2004), and also suggest that the potential distribution of cloud forest will decrease by almost $60 \%$ by the year 2050 . However, in terms of the potential distribution area of tropical evergreen and coniferous forest, we observed a different behavior, since we found a reduction of $97 \%$ for the former and an increase of $21 \%$ for the latter. The substantial reduction in potential distribution of tropical evergreen forest in the region of Veracruz by 2050, as well as in the neighboring states, suggests that changes in temperature and precipitation could be excessive for the physiological tolerance of thermophilic species.

Given that the physiology of these plants has a high synchrony with temperature and also a high requirement of adequate moisture throughout the year, species in the humid tropics may probably have a limited ability to acclimate to global warming (Deutsch et al., 2008; Tewksbury et al., 2008). Likewise, Wright et al. (2009) analyzed the expected behavior of tropical species and forecasted an abrupt fall of tropical forest area, matching changes in the average annual temperature, suggesting that global warming may have severe consequences for species of such vegetation types.

Moreover, the increase in the potential distribution of coniferous forest we found for Veracruz and its neighboring states is consistent with the findings of $\mathrm{Ni}$ 
(2000) in the region of Tibet. He also observed that despite the large area reduction of temperate desert and alpine steppe, among others, there was a sizable expectation of a large increase in the area of temperate-cold coniferous forest, temperate grasslands and shrub, and temperate steppe. As for the state of Veracruz, the results of Benítez et al. (2008) indicate that in 2020 the desert scrub may almost disappear, and for the decade of 2050 the environmental conditions should favor the tropical deciduous forest over the tropical evergreen forest. They also noted that the cloud forest may advance over coniferous and oaks forests. These forecasts, beyond coincidence with our results, are interesting because they highlight the new interactions that plant communities are likely to face in the near future. Contrasting the behavior pattern of the cloud forest of Veracruz obtained by Benitez et al. (2008) with our results, we found in effect that the potential distribution of cloud forest may present a shift towards a higher elevation, but the average values of the potential distribution of coniferous forest suggest a slight descent. We could explain this expected trend of the coniferous forest by considering that these forests have a wide ecological span as they thrive in arid, semi-wet and frankly wet climates, and they may be found from sea level to the upper limit of tree growth (Rzedowski, 1978).

The discrepancies between our work and the studies of Villers and Trejo (1997) and Arriaga and Gómez (2004) may be attributed to methodological differences such as the general circulation models particularly used for their climatic forecasts, the specific environmental variables choice, the pixel size, the algorithm or the starting point of the projections (from vegetation type or a group of species characteristics, etc.). In this regard, we believe that the likely dynamics of the species in response to climate change will more likely take place species by species rather than whole assemblages, as suggested by Thomas et al. (2004), since the response depends mainly on the physiological acclimation of each species. We have to keep in mind that, in addition to physiological tolerances, the potential displacement of each species will be associated with many other factors. For instance, its ability to encompass their life cycle, as well as their opportunity to interact with pollinators and dispersers. Equally important will be the physical availability of locations where to establish, all of which are not part of the forecast approach we used. We hypothesize that species distribution might change at first instance by biotic interactions with animal species or environmental factors involved in their dispersal. Hence, another potential consequence may be the modification of the assemblages of species by the changing ambient conditions.

Individually and considering the different types of vegetation, our results suggest that distribution range of six species will reduce their current potential distribu- 
tion with over $90 \%$, and five of the species could be all together lost from the state of Veracruz by 2050. In contrast, eight species show some sort of increase in potential distribution. A similar study in the Cerrado region in Brazil by Ferreira de Siqueira and Peterson (2003) suggested losses of over 50\% in the potential distribution of most tree species. For Veracruz we found that 24 of the 51 modeled species could suffer losses larger than $50 \%$ of its potential distribution towards the 2050 time horizon. In addition, they present a greater impact on the potential distribution of tropical species, mainly found in the coastal plains, as compared to species of montane areas, most of which do not show such severe losses in potential distribution.

Ferreira de Siqueira and Peterson (2003), also observed this difference in the impact of warm tropical environments compared to temperate species. Peterson (2003b), also pointed out that the species from the plains will be most affected by climate change. However, even if the species characteristics of tropical vegetation show a significant loss risk potential, based on their likely future distribution and the apparent rearrangement of sympatry between plant species, the results of this study suggest likely rearrangements that could modify ecological dominance of current component species, resulting in new species patterns in tropical vegetation types.

Although the models obtained in this paper take into account the characteristic composition of the vegetation types analyzed, our results suggest a possible future emergence of new vegetation types. The loss or reduction of the current dominant species (or of those that characterize each vegetation type) might take place, but the vegetation phenology will largely remain. In this transformation, some species that might currently be non-dominant might find better conditions in the future and become dominant to characterize new vegetation types.

If we would like to encourage the preservation of any kind of vegetation, we should consider changes in land use as well as the distance and the barriers that the composing species must overcome in order to be able to colonize and settle in new areas. Even if the plant species retain their ability to produce fertile propagules, it will be necessary to maintain corridors to facilitate the dispersion towards new climatic zones. The results of this study emphasize the critical importance of safeguarding connectivity by increasing the area and density of networks of protected ecosystems in regions where sources of dispersion are small and widely distributed (Opdam and Wascher, 2004; Da Fonseca et al., 2005; Hannah and Hansen, 2005; Vos et al., 2008).

Therefore, we suggest that in order to minimize the potential loss of plant community members in the future, it is required to change the current static conservation approach towards a new one that undertakes a dynamic adaptive ecosys- 
tem management scheme that recognizes the current spatial reconfiguration stage pressing over the plant communities. The current demands highlight connectivity in addition to the needs of rehabilitation, reforestation and restoration. Ecosystem conservation and management in times of climate change will have to re-design a strategic approach from these elements. It should facilitate the preservation of species currently comprising natural communities, by allowing fast movement so they can quickly colonize and establish in new geographical areas, and there they can continue evolving.

\section{LITERATURE CITED}

Acevedo, R. 1988. La vegetación de la Sierra de Atoyac, Veracruz, México. Tesis de licenciatura. Facultad de Biología, Universidad Veracruzana. Xalapa, Mexico. 102 pp.

Anderson, R. P., M. Gómez-Laverde and A. T. Peterson. 2002. Geographical distributions of spiny pocket mice in South America: insights from predictive models. Glob. Ecol. Biogeogr. 11: 131-141.

Anderson, R. P., D. Lew and A. T. Peterson. 2003. Evaluating predictive models of species' distributions: criteria for selecting optimal models. Ecol. Model. 162: 211-232.

Anonymous. 1975. Guías botánicas de excursiones en México Vol. II: Veracruz, Chiapas y Oaxaca. Sociedad Botánica de México. México, D.F., Mexico. 58 pp.

Anonymous. 2000. Áreas naturales protegidas de Veracruz. Subsecretaría del Medio Ambiente, Editora de Gobierno del Estado de Veracruz. Xalapa, Mexico. 172 pp.

Anonymous. 2001. HYDRO1k Elevation Derivative Database. United States Geological Survey. Washington, USA http://edcdaac.usgs.gov/gtopo30/hydro/

Anonymous. 2003. Conjunto de datos vectoriales de la carta de vegetación primaria 1:1 000000. Instituto Nacional de Estadística, Geografía e Informática. Aguascalientes, Mexico.

Anonymous. 2007. Cambio climático 2007: Informe de síntesis. Contribución de los Grupos de trabajo I, II y III al Cuarto Informe de evaluación del Grupo Intergubernamental de Expertos sobre el Cambio Climático. Pachauri, R. K. and A. Reisinger (eds.). Intergovernmental Panel on Climate Change. Ginebra, Suiza. 104 pp.

Aquino, O. 1996. Flora y vegetación del municipio de Catemaco, Veracruz, México. Tesis de licenciatura. Facultad de Biología, Universidad Veracruzana. Xalapa, México. 133 pp.

Arriaga, L. and L. Gómez. 2004. Posibles efectos del cambio climático en algunos componentes de la biodiversidad en México. In: Martínez, J. and A. Fernández (comps.). Cambio climático: una visión desde México. Instituto Nacional de Ecología-Secretaría de Medio Ambiente y Recursos Naturales. México, D.F., Mexico. pp. 255-265.

Ávila, C. H. and L. López. 2001. Distribución y análisis estructural de Abies hickelii (Flous and Gaussen) en México. Interciencia 6: 244-251. 
Benítez, B. G., H. A. Hernández, Z. M. E. Equihua, C. A. Medina, P. J. L. Álvarez, B. S. Ibañez and A. Ch. Delfin. 2008. Biodiversidad y cambio climático. In: Cejudo, B. A., Z. M. E. Equihua and L. T. García (comp.). Programa Veracruzano ante el Cambio Climático. Universidad Veracruzana - Instituto de Ecología, A.C. Xalapa, Mexico. 37 pp.

Blanco, E. and Y. A. Romero. 1989. Estudio ecológico de la vegetación de los municipios de Alpatlahua y Calcahualco, Veracruz. Tesis de licenciatura. Facultad de Ciencias Biológicas, Universidad Veracruzana. Córdoba, Mexico. 171 pp.

Castillo-Campos, G. 1991. Vegetación y flora del municipio de Xalapa, Veracruz. Instituto de Ecología, A.C. Xalapa, Mexico. 148 pp.

Castillo-Campos, G., R. Robles and M. E. Medina. 2003. Flora y vegetación de la sierra Cruz Tetela, Veracruz, Mexico. Polibótanica 15: 41-87.

Castillo-Campos, G., R. S. Avendaño and M. E. Medina. 2011. Flora y vegetación. In: La biodiversidad en Veracruz, estudio de estado. Comisión Nacional para el Conocimiento y uso de la Biodiversidad, Gobierno del Estado de Veracruz, Universidad Veracruzana, Instituto de Ecología, A.C. Xalapa, Mexico. pp. 163-179.

Chaturvedi, R. K., R. Gopalakrishnan, M. Jayaraman, G. Bala, N. V. Joshi, R. Sukumar and N. H. Ravindranath. 2011. Impact of climate change on Indian forests: a dynamic vegetation modeling approach. Mitig. Adapt. Strat. Glob. Chang. 16: 119-142.

Correa, C. 1981. Cuantificación de la producción de hojarasca en un bosque caducifolio de Xalapa, Veracruz, México. Tesis de licenciatura. Facultad de Ciencias, Universidad Nacional Autónoma de México. México, D.F., Mexico. 42 pp.

Da Fonseca, G. A. B., W. Sechrest and J. Oglethorpe. 2005. Managing the matrix. In: Lovejoy, T. E. and L. Hannah (eds.). Climate change and biodiversity. Yale University Press. New Haven, USA. pp. 346-358.

Del Amo, S. 1978. Crecimiento y regeneración de especies primarias de selva alta perennifolia. Tesis de doctorado. Universidad Nacional Autónoma de México. México, D.F., Mexico. 259 pp.

Deutsch, C. A, J. J. Tewksbury, R. B. Huey, K. S. Sheldon, C. K. Ghalambor, D. C. Haak and P. R. Martin. 2008. Impacts of climate warming on terrestrial ectotherms across latitude. Proc. Nat. Acad. Sci. USA. 105(18): 6668-6672.

Durán, C. M. 1992. La vegetación de la Barranca de las Minas, Veracruz, México. Tesis de licenciatura. Facultad de Biología, Universidad Veracruzana. Xalapa, Mexico. $61 \mathrm{pp}$.

Elith J., C. H. Graham, R. P. Anderson, M. Dudík, S. Ferrier, A. Guisan, R. J. Hijmans, F. Huettmann, J. R. Leathwick, A. Lehmann, J. Li, L. G. Lohmann, B. A. Loiselle, G. Manion, C. Moritz, M. Nakamura, Y. Nakazawa, J. McC. M. Overton, A. T. Peterson, S. J. Phillips, K. Richardson, R. Scachetti-Pereira, R. E. Schapire, J. Soberón, S. Williams, M. S. Wisz, and N. E. Zimmermann. 2006. Novel methods improve prediction of species' distributions from occurrence data. Ecography 29: 129-151.

Elith, J. H., S. J. Phillips, T. Hastie, M. Dudík, Y. E. Chee and C. J. Yates. 2010. A statistical explanation for MaxEnt for ecologists. Divers. Distrib. 17: 43-57.

Engler, R., C. F. Randin, P. Vittoz, T. Czáka, M. Beniston, N. E. Zimmermann and A. Guisan. 2009. Predicting future distributions of mountain plants under climate change: does dispersal capacity matter? Ecography 32: 34-45. 
Ferreira de Siqueira, M. and A. T. Peterson. 2003. Consequences of global climate change for geographic distributions of Cerrado tree species. Biota Neotrop. 3(2): 1-14.

Flores, R. and J. Galindo-González. 2004. Abundancia y diversidad de aves depredadoras de semillas de Pinus teocote Schl. et Cham. en hábitats contrastantes de Veracruz, México. Foresta Veracruzana 6(2): 47-53.

García, J. G., G. Castillo-Campos, K. Mehltreter, M. L. Martínez and G. Vázquez. 2008. Composición florística de un bosque mesófilo del centro de Veracruz, México. Bol. Soc. Bot. Méx. 83: 37-52.

Gerez, P. 1982. Historia del uso del suelo en la zona semiárida Poblana-Veracruzana. Tesis de licenciatura. Facultad de Ciencias, Universidad Nacional Autónoma de México. México, D.F., Mexico. 98 pp.

Godínez, O. and L. López. 2002. Estructura, composición, riqueza y diversidad de árboles en tres muestras de selva mediana subperennifolia. Anales Inst. Biol. Univ. Nac. Autón. México, Ser. Bot. 73(2): 283-314.

Gómez-Pompa, A. 1966. Estudios botánicos en la región de Misantla, Veracruz. Instituto Mexicano de Recursos Naturales Renovables, A.C. México, D.F., Mexico. 173 pp.

Gómez-Pompa, A. 1977. Ecología de la vegetación del estado de Veracruz. Compañía Española de Comunicaciones, S. A. Xalapa, Mexico. 91 pp.

Gómez-Pompa, A., A. Lot, C. Vázquez, M. Soto and N. Diego. 1972. Estudio preliminar de la vegetación y la flora en la región de Laguna Verde, Veracruz. Universidad Nacional Autónoma de México. México, D.F., Mexico. 278 pp.

González, S. E., R. Dirzo and R. C. Vogt. 1997. Historia natural de Los Tuxtlas. Universidad Nacional Autónoma de México. México, D.F., Mexico. 647 pp.

Gutiérrez, C. 1993. Listado florístico de la sierra de Chiconquiaco, Veracruz. Universidad Veracruzana. Xalapa, Mexico. 31 pp.

Hannah, L. and L. Hansen. 2005. Designing landscapes and seascapes for change. In: Lovejoy, T. E. and L. Hannah (ed.). Climate change and biodiversity. Yale University Press. New Haven, USA. pp. 329-341.

Heredia, G. P. 1999. Diversidad y sucesión de los Hyphomycetes de la superficie de las hojas en descomposición de tres especies arbóreas dominantes en un bosque mesófilo de montaña en el centro de Veracruz. Tesis de doctorado. Universidad Nacional Autónoma de México. México, D.F., Mexico. 140 pp.

Hijmans, R. J., S. E. Cameron, J. L. Parra, P. G. Jones and A. Jarvis. 2005. Very high resolution interpolated climate surfaces for global land areas. Int. J. Climatol. 25: 1965-1978.

Holt, R. D. 1990. The microevolutionary consequences of climate change. Trends Ecol. Evol. 5: 311-315.

Holt, R. D. and M. S. Gaines. 1992. Analysis of adaptation in heterogeneous landscapes: implications for the evolution of fundamental niches. Evol. Ecol. 6: 433-447.

Kovach, W. L. 1999. MVSP - A MultiVariate statistical package for Windows, ver. 3.1. Kovach Computing Services. Pentraet, UK.

Lozano, D. F. 1979. Percepción remota de la vegetación de la zona árida Poblano-Veracruzana. Tesis de licenciatura. Facultad de Ciencias, Universidad Nacional Autónoma de México. México, D.F., Mexico. 63 pp. 
Luna, V. E. 1997. Estudio de la vegetación y flora del municipio de Coatepec, Veracruz. Tesis de licenciatura. Facultad de Biología, Universidad Veracruzana. Xalapa, Veracruz. Mexico. 163 pp.

Martínez, J. L. 1988. La vegetación de la zona noreste del Pico de Orizaba, Veracruz, México. Tesis de licenciatura. Facultad de Biología, Universidad Veracruzana. Xalapa, Mexico. 96 pp.

Martínez, J. L. 1993. Aspectos arquitecturales de tres especies arbóreas de la selva alta perennifolia en relación al ambiente lumínico. Tesis de licenciatura. Facultad de Ciencias, Universidad Nacional Autónoma de México. México, D.F., Mexico. 110 pp.

Martínez-Meyer, E., A. T. Peterson and A. G. Navarro. 2004. Evolution of seasonal ecological niches in the Passerina buntings (Aves: Cardinalidae). P. Roy. Soc. Lond. B. Bio. 271: 1151-1157.

Medina-Abreo, M. E. and G. Castillo-Campos. 1993. Vegetación y listado florístico de la Barranca de Acazónica, Veracruz. Bol. Soc. Bot. Méx. 53: 73-111.

Melillo, J. M., I. C. Prentice, G. D. Farquhar, E. D. Schulze and O. E. Sala. 1995. Terrestrial biotic responses to environmental change and feedbacks to climate. In: Houghton, J. T., L. G. Meira Filho, B. A. Callander, N. Harris, A. Kattenberg and K. Maskell (eds.). Climate change 1995: The science of climate change. Cambridge University Press. Cambridge, UK. pp. 445-482.

Miranda, F. and X. E. Hernández. 1963. Los tipos de vegetación de México y su clasificación. Bol. Soc. Bot. Méx. 28: 29-179.

Ni, J. 2000. A simulation of biomes on the Tibetan Plateau and their responses to global climate change. Mt. Res. Dev. 20(1): 80-89.

Opdam, P. and D. Wascher. 2004. Climate change meets habitat fragmentation: linking landscape and biogeographical scale level in research and conservation. Biol. Conserv. 117: 285-297.

Osborne, C. P., P. L. Mitchell, J. E. Sheehy and F. I. Woodward. 2000. Modelling the recent historical impacts of atmospheric $\mathrm{CO}_{2}$ and climate change on Mediterranean vegetation. Global Change Biol. 6: 445-458.

Parra, J. L., C. C. Graham and J. F. Freile. 2004. Evaluating alternative data sets for ecological niche models of birds in the Andes. Ecography 27: 350-360.

Pearson, R. G. and T. P. Dawson. 2003. Predicting the impacts of climate change on the distribution of species: are bioclimate envelope models useful? Global Ecol. Biogeogr. 12: $361-371$.

Pearson, R. G. and T. P. Dawson. 2005. Long distance plant dispersal and habitat fragmentation: identifying conservation targets for spatial landscape planning under climate change. Biol. Conserv. 123: 389-401.

Pearson, R. G., C. Raxworthy, M. Nakamura and A. T. Peterson. 2007. Predicting species' distributions from small numbers of occurrence records: A test case using cryptic geckos in Madagascar. J. Biogeogr. 34: 102-117.

Pennington, T. D. and J. Sarukhán. 1968. Manual para la identificación de campo de los principales árboles tropicales de México. Instituto Nacional de Investigaciones Forestales-FAO. México, D.F., Mexico. 413 pp. 
Peterson, A. T. 2003a. Predicting the geography of species' invasions via ecological niche modeling. Q. Rev. Biol. 78: 419-433.

Peterson, A. T. 2003b. Projected climate change effects on Rocky Mountain and great plain birds: generalities of biodiversity consequences. Global Chang. Biol. 9: 647-655.

Peterson, T. A. and C. K. Cohoon. 1999. Sensitivity of distributional prediction algorithms to geographic data completeness. Ecol. Model. 117: 159-164.

Peterson, A. T., L. G. Ball and K. P Cohoon. 2002. Predicting distributions of Mexican birds using ecological niche modelling methods. Ibis 144: E27-E32.

Peterson, A. T., E. Martínez-Meyer, C. González-Salazar and P. W. Hall. 2004. Modeled climate change effects on distributions of Canadian butterfly species. Can. J. Zool. 82: 851-858.

Peterson, A. T., C. Martínez-Campos, Y. Nakasawa and E. Martínez-Meyer. 2005. Timespecific ecological niche modeling predicts spatial dynamics of vector insects and human dengue cases. T. Roy. Soc. Trop. Med. H. 99: 647-655.

Peterson, A. T., M. Papes and M. Eaton. 2007. Transferability and model evaluation in ecological niche modeling: a comparison of GARP and Maxent. Ecography 30(4): $550-560$.

Peterson, A. T. and A. S. Nyári. 2008. Ecological niche conservatism and Pleistocene refugia in the Thrush-like Mourner, Schiffornis sp., in the Neotropics. Evolution 62(1): 173183.

Phillips, S. J., R. P. Anderson and R. E. Schapire. 2006. Maximum entropy modeling of species geographic distributions. Ecol. Model. 190: 231-259.

Ramírez, F. 1999. Flora y vegetación de la Sierra de Santa Marta, Veracruz. Tesis de licenciatura. Facultad de Ciencias, Universidad Nacional Autónoma de México. México, D.F., Mexico. 409 pp.

Ramírez, F. and J. Palma. 1980. Proyecto para el establecimiento de una reserva ecológica en Huayacocotla, Veracruz, México. Instituto Nacional de Investigaciones sobre Recursos Bióticos. Xalapa, Veracruz. Mexico. 159 pp.

Ramírez, G. B. 1981. Estudio químico y biológico de algunas plantas de selva alta perennifolia y acahual. Tesis de licenciatura. Facultad de Química, Universidad Nacional Autónoma de México. México, D.F., Mexico. 80 pp.

Ramírez, M. 1998. Influencia de la actividad humana sobre las propiedades edáficas del horizonte A, en los paisajes de una cuenca del Parque Nacional Cofre de Perote, Veracruz. Tesis de licenciatura. Facultad de Filosofía y Letras, Universidad Nacional Autónoma de México. México, D.F., Mexico. 124 pp.

Ruán, I. 2006. Efectos de la fragmentación sobre las comunidades de pequeños mamíferos en remanentes de bosque mesófilo de montaña del centro de Veracruz. Tesis de maestría. Instituto de Ecología A.C. Xalapa, Mexico. 64 pp.

Rzedowski, J. 1978. Vegetación de México. Limusa. México, D.F., Mexico. 432 pp.

Rzedowski, J. 1996. Análisis preliminar de la flora vascular de los bosques mesófilos de montaña de México. Acta Bot. Mex. 35: 25-44.

Scheiter, S. and S. I. Higgins. 2009. Impacts of climate change on the vegetation of Africa: an adaptive dynamic vegetation modeling approach. Global Change Biol. 15: 22242246. 
Still, C. J., P. N. Foster and S. H. Schneider. 1999. Simulating the effects of climate change on tropical montane cloud forests. Nature 398: 15-17.

Stockwell, D. and D. Peters. 1999. The GARP modelling system: problems and solutions to automated spatial prediction. Int. J. Geogr. Inf. Sci. 13(2): 143-158.

Tewksbury, J. J., R. B. Huey and C. A. Deutsch. 2008. Putting the heat on tropical animals. Science 320: 1296-1297.

Thomas, C. D., C. Alison, R. E. Green M. Bakkenes, L. J. Beaumont, Y. C. Collingham, B. F. N. Erasmus, M. Ferreira de Siqueira, A. Grainger, L. Hannah, L. Hughes, B. Huntley, A. S. Jaarsveld, G. F. Midgley, L. Miles, M. A. Ortega-Huerta, A. T. Peterson, O. L. Phillips and S. E. Williams. 2004. Extinction risk from climate change. Nature 427(8): 145-148.

Tsoar, A, O. Allouche, O. Steinitz, D. Rotem and R. Kadmon. 2007. A comparative evaluation of presence-only methods for modeling species distribution. Divers. Distrib. 13: 397405.

Valdivia, P. E. 1976. Estudio de las plantas epifitas de la región de Uxpanapa, Veracruz, México. Tesis de licenciatura. Facultad de Ciencias, Universidad Nacional Autónoma de México. México, D.F., Mexico. 44 pp.

Vázquez, V. 1977. Contribución al estudio de la vegetación de la región de Zongolica, Veracruz. Tesis de licenciatura. Facultad de Biología, Universidad Veracruzana. Xalapa, Mexico. 120 pp.

Vázquez, S. M. 1989. Riqueza de plantas vasculares y la diversidad de especies arbóreas del dosel superior en 5 ha. de selva tropical cálido-húmeda en la zona de Uxpanapa, Ver. Tesis de Maestría. Colegio de Postgraduados. Chapingo, Mexico. 294 pp.

Vetaas, O. R. 2002. Realized and potential climate niches: a comparison of four Rhododendron tree species. J. Biogeogr. 29: 545-554.

Villers, R. L. and I. Trejo. 1997. Assessment of the vulnerability of forest ecosystems to climate change in Mexico. Clim. Res. 9: 87-93.

Vos, C. C., P. Berry, P. Opdam, H. Baveco, B. Nijhof, J. O’Hanley, C. Bell and H. Kuipers. 2008. Adapting landscapes to climate change: examples of climate-proof ecosystem networks and priority adaptation zones. J. Appl. Ecol. 45: 1722-1731.

Warren, D. L., R. E. Glor and M. Turelli. 2008. Environmental niche equivalency versus conservatism: quantitative approaches to niche evolution. Evolution 62: 2868-2883.

Williams-Linera, G. 1982. Biomasa y contenido de nutrientes en la vegetación y el suelo de dos etapas sucesionales de una selva alta perennifolia. Instituto Nacional de Investigaciones sobre Recursos Bióticos. Xalapa, México. 30 pp.

Williams-Linera, G. 2007. El bosque de niebla del centro de Veracruz: Ecología, historia y destino en tiempos de fragmentación y cambio climático. Comisión Nacional para el Conocimiento y Uso de la Biodiversidad-Instituto de Ecología, A.C. México, D.F. Mexico. 208 pp.

Wright, S. J., H. C. Muller-Landau and J. Schipper. 2009. The future of tropical species on a warmer planet. Conserv. Biol. 23(6): 1418-1426.

Zamora, P. and G. Castillo-Campos. 1997. Vegetación y flora del municipio de Tlalnelhuayocan, Veracruz. Textos Universitarios, Universidad Veracruzana. Xalapa, Mexico. 88 pp. 
Zolá, M. 1980. Estudio de la vegetación de los alrededores de Xalapa, Veracruz. Tesis de licenciatura. Facultad de Biología, Universidad Veracruzana. Xalapa, Mexico. 118 pp.

Zolá, M. 1984. La vegetación de Xalapa, Veracruz. Instituto Nacional de Investigaciones sobre Recursos Bióticos. Xalapa, Veracruz. Mexico. 115 pp.

Recibido en junio de 2013.

Reactivado en febrero de 2014.

Aceptado en marzo de 2015. 